\title{
Deltamethrin resistance in Chagas disease vectors colonizing oil palm plantations: implications for vector control strategies in a public health-agriculture interface
}

\author{
Johan M. Calderón ${ }^{{ }^{*}} \mathbb{0}$, Patricia Fuya² ${ }^{2}$ Liliana Santacoloma² and Camila González
}

\begin{abstract}
Background: Triatomine bugs are responsible for the vectorial transmission of the parasite Trypanosoma cruzi, etiological agent of Chagas disease, a zoonosis affecting 10 million people and with 25 million at risk of infection. Several triatomine species of the genus Rhodnius have been found inhabiting palm crowns where insects can find shelter in leaves axils and blood from palm-associated vertebrates. Rhodnius prolixus insects have been collected in oil palms in Colombia, and high T. cruzi infection rates were found. Since pest control is carried out in oil palm plantations, continuous exposure to insecticides could be occurring in these triatomines. Some insecticides suggested for pest control in oil palm plantations are also recommended for triatomine control in human dwellings. In this study, our objective was to assess if triatomines inhabiting oil palms exhibit resistance to deltamethrin, an insecticide used for vector control.
\end{abstract}

Methods: Rhodnius prolixus nymphs were sampled in oil palms located in Tauramena, Colombia. To determine deltamethrin resistance, biological and biochemical assays were carried out on fifth-instar nymphs from the F1 generation. For biological assays, pure and commercial deltamethrin were used, and in biochemical assays, activities of detoxifying enzymes related to pyrethroid resistance, such as oxidases, esterases and transferases, were quantified.

Results: Deltamethrin lethal dosage 50 and 90 in R. prolixus from oil palms was significantly higher than in those from a susceptible colony suggesting possible deltamethrin resistance. Moreover, mortality with commercial deltamethrin was very low in insects from oil palms. In biochemical assays, the activity of evaluated detoxifying enzymes was significantly higher in R. prolixus from oil palms than in those from the susceptible colony.

Conclusions: Possible deltamethrin resistance found in $R$. prolixus insects from oil palms could threaten traditional vector control strategies in urban settings if insecticide-resistant triatomines can migrate from oil palms plantations. In palm oil producer countries such as Colombia, the oil palm plantations are growing constantly during the last years. We suggest that pest control strategies in oil palm crops should include triatomine surveillance and toxicological monitoring, especially in zones with several Chagas disease cases.

Keywords: Chagas disease, Triatominae, Insecticide resistance, Biological pest control, Oil palms

\footnotetext{
*Correspondence: jm.calderon@uniandes.edu.co

${ }^{1}$ Centro de Investigaciones en Microbiología y Parasitología Tropical

(CIMPAT), Departamento de Ciencias Biológicas, Universidad de Los Andes, Bogotá D.C., Colombia

Full list of author information is available at the end of the article
}

\section{Background}

Triatomine bugs are responsible for the vectorial transmission of the parasite Trypanosoma cruzi, etiological agent of Chagas disease, a zoonosis affecting almost 1.3 million people in Colombia, where 3.5 million inhabit areas with high risk of infection [1]. According to the 
World Health Organization (WHO) [2], insecticide spraying is the main strategy for vector control in Chagas disease transmission scenarios. Chemical control is based on spraying human dwellings and peridomestic areas with insecticide formulations applied by professional sprayers [3]. This intervention has led to a reduction of the spatial distribution of important Chagas disease vectors, such as Triatoma infestans in the southern cone, and to interruption of parasite transmission [4].

In the 1990s, insecticide resistance in triatomines was considered unlikely due to their long life-cycle (approximately 5-6 months, but it can vary according to species) and low genetic variability $[3,5,6]$. However, in the following years, several reports of insecticide resistance in triatomines have been published. In 1966, the first evidence of triatomines surviving to insecticide dosages used in field was reported for Rhodnius prolixus insects from laboratory colonies exposed to organophosphates and organochlorides [7].

Three mechanisms have been found related to the development of insecticide resistance in triatomines: reduced penetration (reducing insecticide entry); enhanced metabolism (increasing insecticide degradation); and modified site of action (reducing the binding of the target with the insecticide). Reduced insecticide penetration can be the result of changes in insect cuticle [8]. Enhanced metabolism occurs when a group of detoxifying enzymes, such as monooxygenases, esterases and glutathione $\mathrm{S}$-transferases, act over the insecticide reducing the amount that affects the organism [3]. A modified site of action, which is a consequence of punctual mutations $[3,6]$, decreases considerably insecticide-target bonding.

In the case of Chagas disease transmission, the main concern for insecticide resistance is related to the risk of vector domiciliation from palms to households, controlled with spraying. A novel epidemiological scenario has arisen in Colombia due to the introduction of massive extensions of oil palm plantations covering almost 630,000 hectares (ha) in 2016 [9]. Rhodnius prolixus nymphs and adults infected with $T$. cruzi have been collected from several oil palm plantations (Elaeis guineensis palms) [10, 11]. From 2007 to 2016, the total oil palm cultivated area in Colombia has grown by $95 \%$, covering 127 municipalities mostly distributed in the central and north regions of the country [9] (Fig. 1). Of these, 53 municipalities have reported presence of palm-infesting triatomines (e.g. R. pallescens, R. prolixus and Triatoma dimidiata [12-15]) and Chagas disease cases (source: SIVIGILA); also, oil palm cultivated area in these municipalities has increased steadily, with a growth of $116 \%$ from 2007 to 2016 [9].

As any widely extended monocrop, oil palm plantations are affected by pests, which deteriorate different organs of the palm. Chemical control is as well one of the strategies used for pest control in oil palms [16, 17]. Systemic herbicides are applied in the palm stem to avoid pest colonization, and after palm pruning, exposed plant tissue is protected from pests by the application of insecticides [18]. Some insecticides suggested or used for the control of important oil palm pests are also recommended by the Pan American Health Organization (PAHO/ WHO) to control triatomines in domiciles, as is the case for $\lambda$-cyhalothrin, cypermethrin and deltamethrin [19]. Alfa-cyhalothrin has been suggested to control the palm root pests Strategus aloeus (ox beetle) [20] and the moth Sagalassa valida [21, 22]; cypermethrin has been recommended to control the palm defoliator Opsiphanes cassina (split-banded owlet) [23], and deltamethrin has been suggested to control the important palm pest Rhynchophorus palmarum (South American palm weevil) [24].

Chemical pest control in oil palm plantations could be exposing triatomines living in palms to insecticides recommended for Chagas vector control. This exposure could promote the development of resistance to those insecticides in triatomines, and further, if insecticideresistant triatomines migrate from oil palms to urban settings, traditional vector control strategies would be inefficient. Although agricultural development and public health are globally pillars of government agendas, a need for coordinated efforts may have been underestimated; as a result, important implications of independent decision-making could arise. From this perspective, the aim of this study was to assess if triatomines inhabiting oil palms exhibit resistance to insecticides used for vector control, by using biological and biochemical assays.

\section{Methods}

\section{Insect sampling}

Triatomine collection was carried out in Hacienda Potrillos $\left(72^{\circ} 36^{\prime} 30.2538^{\prime \prime} \mathrm{W}, 4^{\circ} 59^{\prime} 4.311^{\prime \prime} \mathrm{N}\right)$ located in Tauramena (Casanare, Colombia), in an E. guineensis (oil palm) plantation located near ( $30 \mathrm{~m})$ an Attalea butyracea (native palm) cluster in a riparian forest. Attalea butyracea palms have infestation reports by $R$. prolixus in the region [25, 26]. Insect sampling was performed on July 2017 (rainy season) in 20 E. guineensis palms in the plantation and $20 \mathrm{~A}$. butyracea palms in the forest. Triatomines were collected using modified Angulo traps [27], with one trap per palm from 18:00 h to 7:00 $h$. Traps were located in the crowns of the palms close to leaf axils. A total number of 30 R. prolixus nymphs were collected from E. guineensis and $30 R$. prolixus nymphs from $A$. butyracea. Triatomines from native palms were collected to be used as control for sylvatic insects, assuming a lower exposure to insecticides. Collected $R$. prolixus individuals were transported alive to the Research 


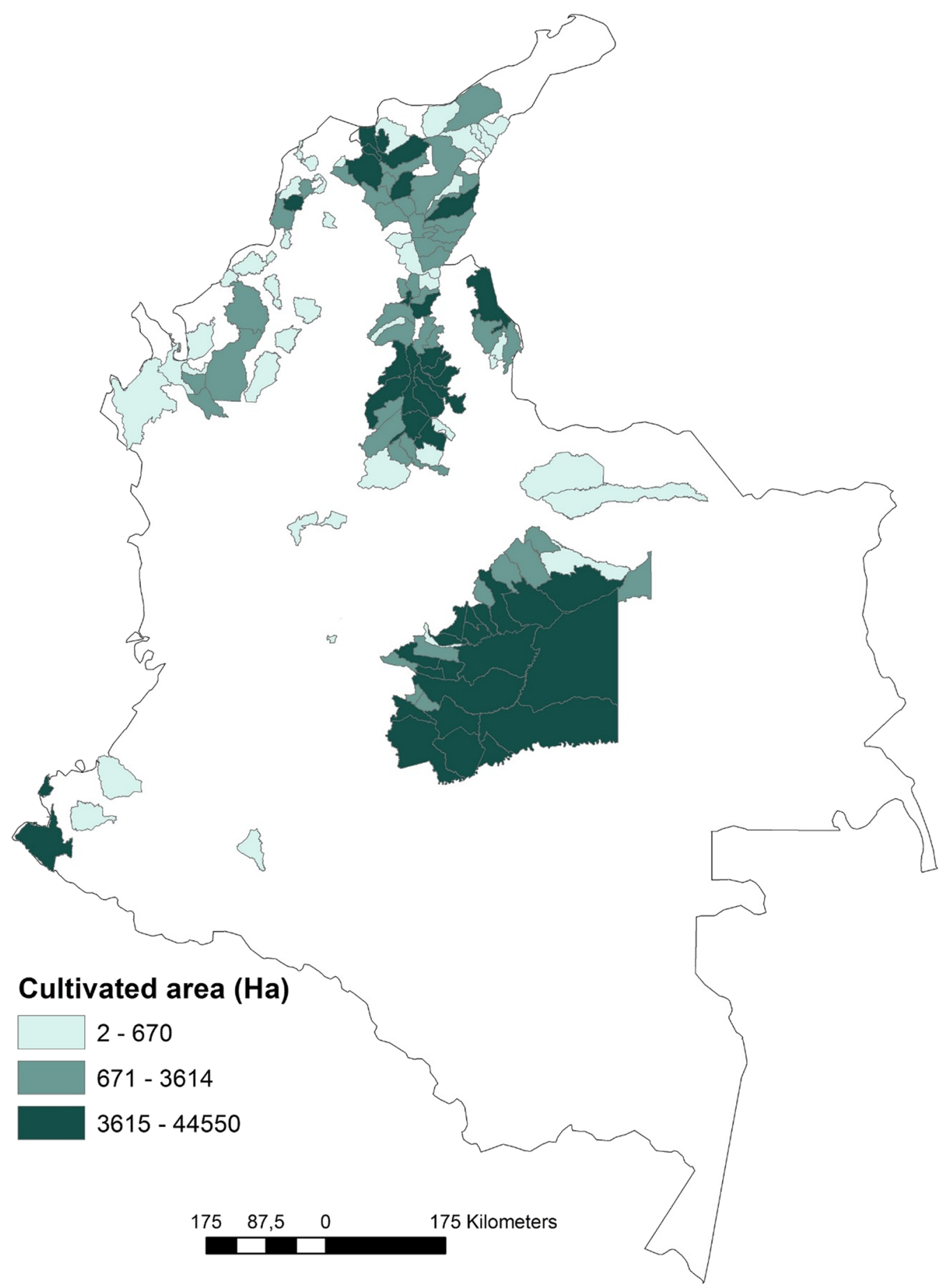

Fig. 1 Municipalities with oil palm plantations in 2016 discriminating by cultivated area. Data source: Ministerio de Agricultura [9]. Elaborated with ArcGis 10.4.1

Center for Microbiology and Tropical Parasitology (CIMPAT by its acronym in Spanish) at the Universidad de Los Andes, Bogotá, and kept in the insectary to establish a colony and obtain F1 nymphs. Insectary conditions were temperature of $26^{\circ} \mathrm{C}$ and relative humidity (RH) of $76 \%$, with 30 insects per breeding cage. Insects were fed with chicken blood for 20 min weekly. When eggs were 
laid, they were transferred to another breeding cage to separate F1 from parental insects.

Triatomine species identification was determined morphologically based on Lent \& Wygodzinsky [28]. Additionally, species identity confirmation was carried out in 16 randomly selected individuals by sequencing a 682-bp DNA fragment of the cytochrome $b$ gene using primers cytb7432F (5'-GGA CG(AT)G G(AT)AT TTA TTA TGG ATC-3') and cytb7433R (5'-GC(AT) CCA ATT CA(AG) GTT A(AG)T AA-3') [29].

\section{Biological assays}

To estimate insecticide resistance, three groups of $R$. prolixus from different origins, i.e. oil palms, native palms and a reference susceptible colony (control) were tested. The control colony, maintained at CIMPAT, was established from wild populations collected in El Viso $\left(5^{\circ} 00^{\prime} 10^{\prime \prime} \mathrm{N}, 72^{\circ} 42^{\prime} 25^{\prime \prime} \mathrm{W}\right)$, Mani Municipality (Casanare, Colombia) in March 2009 (no wild individuals have been further introduced into the colony).

The insecticide selected for the assays was the synthetic pyrethroid deltamethrin (DM), which is one of the insecticides recommended by the PAHO/WHO for triatomine vector control in domiciles [19]. Lethal dosages 50\% (LD50) and 90\% (LD90) were estimated.

Biological assays were carried out using the protocol designed by the WHO for triatomines [30]. Four DM concentrations were tested: 0.006, 0.03, 0.06 and $0.3 \mathrm{ng}$ $\mathrm{DM} /$ insect (Deltamethrin Pestanal ${ }^{\circledR}$, analytical standard; Sigma-Aldrich, St. Louis, USA) using acetone as solvent. For each concentration, three replicates were carried out, and for each replicate, 10 insects were used (F1 nymphs in five-instar, one week after moulting). Each insect was exposed to $0.6 \mu \mathrm{l}$ of DM solution in the dorsal abdomen using a Hamilton ${ }^{\circledR} 10 \mu \mathrm{l}$ microsyringe (with a PB-600 repeating dispenser; St. Louis, USA). Nymphs were kept in Petri dishes with a $5 \mathrm{~cm}^{2}$ paper and transported to other insectary to protect insects in the colony $\left(26^{\circ} \mathrm{C}\right.$ and $76 \%$ RH). Mortality was observed after $72 \mathrm{~h}$. An insect was considered dead when it was placed on filter paper and there was no locomotive activity, either spontaneous or after stimulation with a paintbrush.

To estimate resistance to commercial insecticide, biological assays were performed with commercial DM formulation, K-othrine ${ }^{\circledR}$ (Bayer, Leverkusen, Germany). Filter paper disks $(9 \mathrm{~cm}$ in diameter) were impregnated with $1 \mathrm{ml} \mathrm{K}$-othrine ${ }^{\circledR}\left(10 \mathrm{ml} \mathrm{K}\right.$-othrine ${ }^{\circledR} / 0.8 \mathrm{l}$ water; this is the concentration suggested by the fabricant for the use of K-othrine ${ }^{\circledR}$ in metallic aspersers). Paper disks were airdried for $24 \mathrm{~h}$. Ten nymphs (fifth-instar) were placed in a Petri dish with an impregnated paper disk and remained there for $1 \mathrm{~h}$. Then, they were moved to Petri dishes with a $5 \mathrm{~cm}^{2}$ paper inside and transported to the insectary $\left(26{ }^{\circ} \mathrm{C}\right.$ and $\left.76 \% \mathrm{RH}\right)$. Mortality was observed after $72 \mathrm{~h}$. Assays were performed for insects from each origin, and a negative control (paper disks impregnated with water).

\section{Biochemical assays}

To identify biochemical mechanisms related to insecticide resistance, enzymatic activity was evaluated in $\alpha$-esterases, $\beta$-esterases, glutathione $S$-transferases (GST), and mixed-function oxidases (MFO) of the triatomines. These enzymes are involved in metabolic mechanisms associated to pyrethroid resistance [3]. The technique by Valle et al. [31] was used with some modifications for triatomines by Davila-Barboza et al. [32].

From each origin, $30 \mathrm{~F} 1 \mathrm{fifth}$-instar nymphs were used (one week after molting). Nymphs were homogenized individually in MilliQ grade water, and the homogenate was centrifuged at $12,000 \times r p m$ for $60 \mathrm{~s}$, after taking an aliquot for MFO assays. The homogenate was placed in wells of a flat-bottom microplate in duplicate and the absorbance was measured in a SmartReader 96 microplate reader (Benchmark Scientific, Sayreville, USA). Alpha- and $\beta$-esterase activities were determined using $\alpha$-naphtyl and $\beta$-naphtyl esters as substrates (1-naphthyl acetate $>98 \%$ and 2-naphtyl acetate esterase substrate; Sigma-Aldrich) and measuring product concentration (absorbance at $570 \mathrm{~nm}$ ). The MFO content was determined by measuring the heme content in the insect (absorbance at $650 \mathrm{~nm}$ ). For GST, the activity was determined by conjugation of the thiol group of glutathione to the substrate, 1-chloro-2, 4-dinitrobenzene (> 99\%, Sigma-Aldrich; absorbance at $340 \mathrm{~nm}$ ). Total protein was determined by the Bradford method, which was used to correct the activity values for the evaluated enzymes.

\section{Data analysis}

LD50 and LD90 were estimated using generalized linear models (GLM) with binomial family and probit link function (recommended by the WHO bioassays protocol). Other GLM models were tested, binomial family/ logit link function and quasibinomial family, but residual deviance did not decrease (e.g. residual deviance with colony insects: binomial/probit $=15.578$; binomial $/$ logit $=16.649$; quasibinomial: 16.649). Moreover, estimated LD50 and LD90 did not change between GLM models (e.g. LD50 with colony insects: binomial/probit $=0.0120 \mathrm{ng} /$ insect; binomial $/$ logit $=0.0120 \mathrm{ng} /$ insect; quasibinomial $=0.0120 \mathrm{ng} / \mathrm{insect}$ ). Estimated LD50 and LD90 were compared among $R$. prolixus origins using the ratio test suggested by Wheeler et al. [33] and performed with the $d r c$ R package [34]. If the confidence interval for the ratio of the LDs contains 1 , no significant difference exists. The grade of resistance was determined as the ratio between LD50 in insects from palms (oil or native 
palms) and LD50 in insects from the susceptible colony [30].

Enzymatic activity was calculated as mass of product/ mass of protein/time. Alfa-esterase activity was reported as $\mathrm{nmol} \alpha$-naphtol $/ \mathrm{mg}$ protein $/ \mathrm{min}, \beta$-esterase activity as nmol $\beta$-naphtol $/ \mathrm{mg}$ protein $/ \mathrm{min}$, and GST activity as $\mathrm{nmol}$ product $/ \mathrm{mg}$ protein/min. MFO was not reported as enzymatic activity, but as $\mu \mathrm{g}$ of heme group/mg protein. Enzymatic activity was compared between $R$. prolixus origins by Kruskal-Wallis test $(\alpha=0.05)$ and a posteriori pairwise contrasts by Wilcoxon tests (Bonferroni $P$-value adjusted method).

\section{Results}

\section{Biological assays}

The LD50 and LD90 values in $R$. prolixus from oil palms were significantly higher than those from the susceptible colony (LD50 Ratio $=5.055 \pm 1.874$ (estimate \pm standard error), 95\% CI: $1.381-8.729$; LD90 Ratio $=4.797 \pm 0.226$, 95\% CI: 4.354-5.239) (Table 1 and Fig. 2). In native palms, the LD90 value was significantly higher than in the susceptible colony (LD90 Ratio $=1.531 \pm 0.157,95 \%$ CI: 1.224-1.838), and LD50 was also higher but not significant (LD50 Ratio $=2.538 \pm 1.389,95 \%$ CI: $-0.184-$ 5.261) (Table 1 and Fig. 2). The degree of resistance in oil palms was 5.042 and in native palms 2.542, the LD50 in $R$. prolixus from oil palms being 1.983 times higher than in native palms. Precisely, both lethal dosages were higher in oil palms than in native palms although LD50 was not significant (LD50 Ratio $=1.991 \pm 0.517,95 \%$ CI: 0.9773.005; LD90 Ratio $=3.133 \pm 0.120,95 \%$ CI: 2.896-3.369). These results suggest the evolution of DM resistance in both oil and native palms. Nevertheless, it is important to note that the nymphs from the susceptible colony had a lower mean weight than those from native and oil palms (Table 1).

In assays with the commercial insecticide formulation, mean mortality was much lower in $R$. prolixus insects from oil palms than in those from the susceptible colony, and between palms, lower in oil palms than in native palms (Table 2), corroborating the higher insecticide resistance of $R$. prolixus from oil palms. In contrast to the assays with the pure DM, the nymphs from the susceptible colony did not have a lower mean weight than those from native and oil palms (Table 2).

\section{Biochemical assays}

Enzymatic activity differed significantly among $R$. prolixus from oil palms, native palms and the colony for all the detoxifying enzymes tested: MFO (KruskalWallis test: $\left.X^{2}=34.421, d f=2, P<0.0001\right), \alpha$-esterases $\left(\chi^{2}=59.995, d f=2, P<0.0001\right), \beta$-esterases $\left(\chi^{2}=51.121\right.$, $d f=2, \quad P<0.0001) \quad$ and GST $\left(x^{2}=59.988, \quad d f=2\right.$, $P<0.0001)$. MFO activity was higher in oil palms than in the colony (Wilcoxon rank sum test: $P<0.0001$ ), but not different to native palms $(P=0.076)$ (Fig 3). Alfa-esterases activity was higher in oil palms than in native palms $(P<0.0001)$ and the colony $(P<0.0001)$ (Fig 3$)$. Activity of $\beta$-esterases in oil palms was very similar to native palms, although it was still higher than in the susceptible colony $(P<0.0001)$ (Fig 3). Finally, GST activity in oil palms was higher than in the colony $(P<0.0001)$, but it was lower than in native palms $(P=0.0009)$ (Fig 3$)$.

\section{Discussion}

The present results show the evolution of deltamethrin resistance in insects collected from the field when compared to insects from the colony. Deltamethrin (DM) is a pyrethroid that acts on nerve membranes by delaying the closing of the activation gate for the sodium ion channel [35]. Pyrethroids are preferred for triatomine control in domiciles because they are applied at lower doses (costeffective), have great acceptability both by householders and sprayers, are odorless, and leave no stains on the walls after application [3]. Pyrethroid resistance has been reported previously in triatomines; first evidence was reported in $R$. prolixus from Carabobo (Venezuela) and in T. infestans from Río Grande do Sul (Brazil) [36]. In our study, $R$. prolixus collected from oil palms would indicate resistance to DM pure and the commercial version. This possible resistance to DM in $R$. prolixus could be caused by continuous exposition to this insecticide. DM has been suggested for control of Rh. palmarum in oil palms [24], and this insecticide showed the lowest LD50 for Rh. palmarum in bioassays that evaluated

Table 1 Deltamethrin LD50 and LD90 in R. prolixus from each origin

\begin{tabular}{|c|c|c|c|c|}
\hline Source & $n^{\mathrm{a}}$ & Mass of each insect $(\mathrm{mg})^{b}$ & LD50 (ng DM/insect) ${ }^{c}$ & LD90 (ng DM/insect) ${ }^{c}$ \\
\hline Susceptible & 150 & $53.2 \pm 12.3$ & $0.0120 \pm 0.0034$ & $0.0966 \pm 0.0382$ \\
\hline Native palms & 150 & $76.4 \pm 8.24$ & $0.0305 \pm 0.0058$ & $0.1480 \pm 0.0497$ \\
\hline Oil palms & 150 & $79.5 \pm 9.70$ & $0.0605 \pm 0.0142$ & $0.4636 \pm 0.2524$ \\
\hline
\end{tabular}

\footnotetext{
a Number of insects

${ }^{\mathrm{b}}$ Mean \pm standard deviation

c Regression estimate \pm standard error
} 


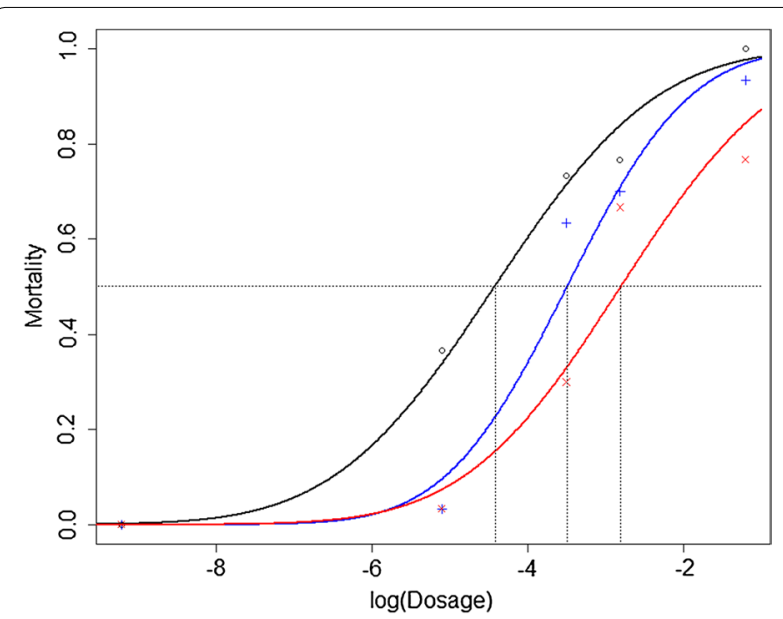

Fig. 2 Response-dosage curves. Lines: probit logistic models. Points: mean mortality. Key: red, R. prolixus from oil palms; blue, R. prolixus from native palms; black, R. prolixus from a susceptible colony

Table 2 Mortality in R. prolixus from different sources caused by commercial deltamethrin

\begin{tabular}{lllll}
\hline Source & $n^{\mathrm{a}}$ & $\begin{array}{l}\text { Mass of each } \\
\text { insect }(\mathrm{mg})^{\mathrm{b}}\end{array}$ & & \multicolumn{2}{l}{ Mean mortality (\%) } \\
\cline { 4 - 5 } \cline { 4 - 5 } & & & Control & Insecticide $^{\mathrm{b}}$ \\
\hline Susceptible & 40 & $80.2 \pm 4.1$ & 0 & $90.0 \pm 10.0$ \\
Native palms & 40 & $66.9 \pm 3.9$ & 0 & $43.3 \pm 40.4$ \\
Oil palms & 40 & $81.0 \pm 4.2$ & 0 & $10.0 \pm 0$ \\
\hline
\end{tabular}

a Number of insects

b Mean \pm standard deviation

several insecticides [24]. Control of Rh. palmarum is extremely important for oil palm plantations. Larvae tunnel into the crown and trunk, and the tissues around the growing point begin to decay and the palm may die [37]. Furthermore, there is an apparent association between Rh. palmarum and bud rot disease, a disease that has destroyed more than 70,000 ha of oil palm plantations in the western and central regions of Colombia [38].

An important consideration to include here is the possible role of the nymph weight on the previous results. In the biological assays with the pure DM, mean weight was greater in nymphs from native and oil palms (with lower mortality) than in those from the susceptible colony (with higher mortality) (Table 1). If insects only differed in individual weight, nymphs with higher weight would require a higher dose of insecticide to obtain the same toxicological result than nymphs with less weight. Differences in nymph weight as well as in insecticide susceptibility could explain the higher deltamethrin resistance found in nymphs from palms. However, this relationship between weight and mortality was not observed between native and oil palms, and in the commercial DM bioassays. Mean nymph weight in native and oil palms was very similar but their LD90s were significantly different (Table 1), and in commercial DM assays, nymph weight in the susceptible colony and oil palms were very similar but their mortalities were extremely different (Table 2). Therefore, we should not discard a possible effect of nymph weight on the obtained mortality values, but its impact has nonetheless shown no consistency among all the bioassays.

Enhanced metabolism could be occurring in $R$. prolixus from oil palms as a biochemical mechanism related to insecticide resistance. All detoxifying enzymes studied had higher activity in $R$. prolixus from oil palms than in the susceptible ones. Detoxifying enzymes could be acting over DM reducing the amount that affects the organism [3]. In $R$. prolixus populations from Venezuela and T. infestans from Brazil with resistance to deltamethrin, $\beta$-cyfluthrin and cypermethrin, monooxygenases activity was higher than in a susceptible lineage [36]. Moreover, esterases and monooxygenases have shown to be involved in pyrethroid resistance in T. infestans from Argentina [39-42].

Higher enzymatic activity in detoxifying enzymes may help $R$. prolixus insects to reduce their susceptibility to DM. Alfa- and beta-esterases may contribute to DM resistance by rapidly binding and slowly turning over the insecticide. Esterases apparently sequester insecticide rather than metabolize it [43]. MFOs are a large group of enzymes that play an important role in insects for the regulation of endogenous compounds and the metabolism of exogenous substances [43]. Elevated MFO activity has been associated with pyrethroid resistance [44]. GSTs are dimeric multifunctional enzymes that play a role in detoxification of a large range of xenobiotics including insecticides [45].

DM resistance was also observed in $R$. prolixus from native palms (pure and commercial version), but the degree of resistance was lower than in $R$. prolixus from oil palms. Additionally, all detoxifying enzymes studied, had higher activity in $R$. prolixus from native palms than in the susceptible ones.

Since native palms have not been sprayed with insecticides, possible resistance in $R$. prolixus from native palms could be related to insect migration between both palm types. Native and oil palms in the sampling site were very close $(\sim 30 \mathrm{~m})$ and Rhodnius adults have demonstrated to fly much longer distances [46, 47]. Moreover, several vertebrate host species have been found in both riparian forest and oil palm plantations [11], and they could be circulating between these habitats transporting triatomines. Both palm types, native and oil palms have 


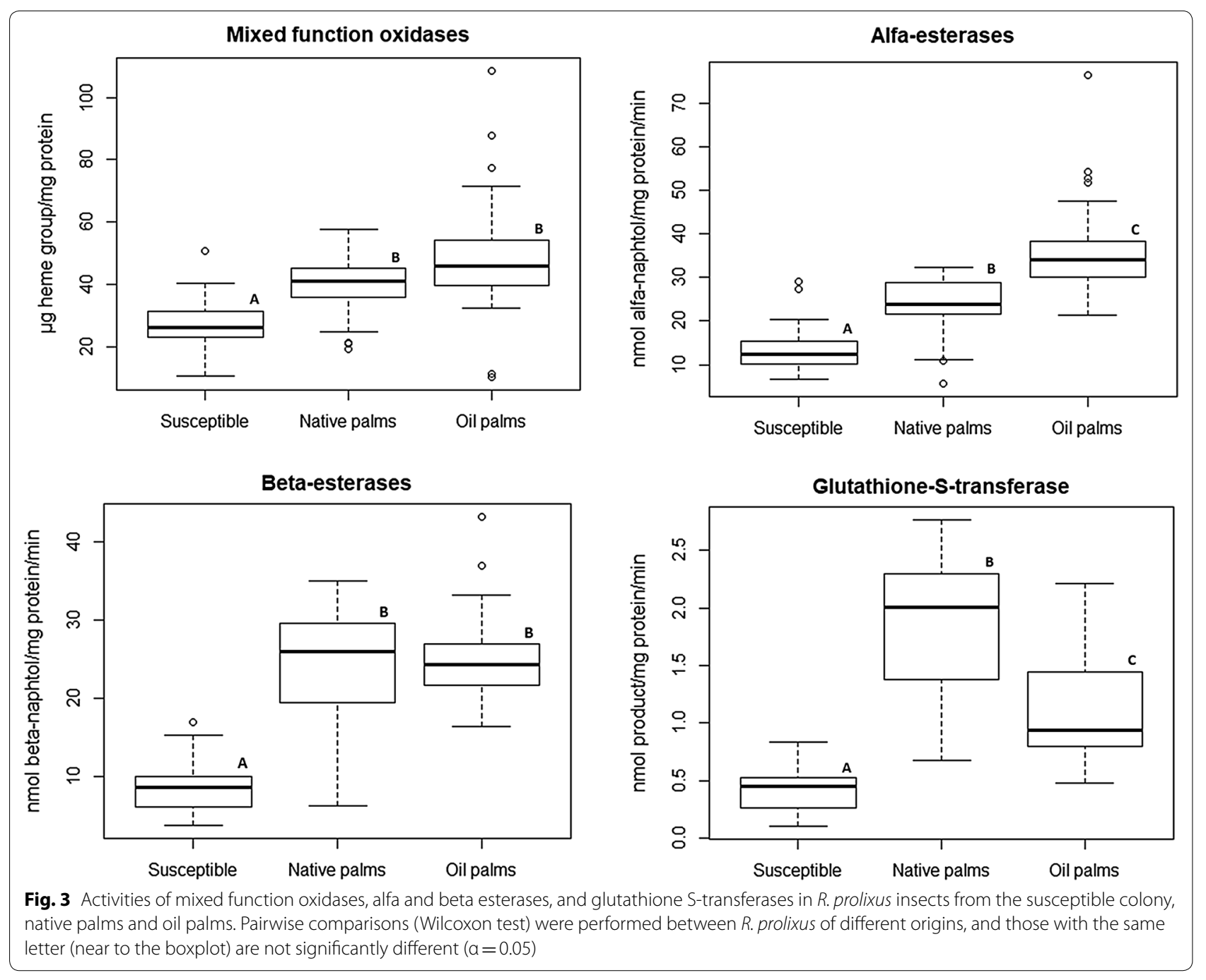

demonstrated suitable conditions for the sustainability of R. prolixus populations (e.g. host availability) $[11,26]$.

This scenario may be of concern for public health if resistant triatomines from oil palms colonize urban settings because traditional vector control may be inefficient. Triatomine migration from native palms toward houses has been demonstrated by morphometric and molecular studies $[29,48]$. Triatomine migration can be triggered by the decrease of refuges and hosts by habitat degradation, human colonization of forested areas in low quality houses, and the attraction of bugs to artificial lights in houses at night [49-52].

Pest attacks in oil palm plantations may cause important economic losses for the oil palm cultivators. Colombia is currently the main oil palm producer in America. The expanding national and international biofuel market has stimulated much interest in biodiesel production in Colombia, especially given that the government has the ambitious goal of producing biodiesel, by replacing $20 \%$ of diesel with biofuel [53]. Nevertheless, triatomine presence in oil palm plantations should not be ignored, and it would be indicating a new important scenario of T. cruzi transmission [11].

Pest management in oil palm plantations must consider its impact over triatomines, and there is a need to consider a pest control strategy that also includes a triatomine vector control. We considered a complete strategy involving several procedures. First, the municipalities of Colombia with actual presence of triatomines in oil palm plantations must be identified. Entomological surveillance should be done in municipalities with both oil palm plantations and reported triatomine vectors 
(e.g. Rhodnius prolixus). Oil palm plantations and adjacent areas such as riparian forests should be monitored to determine triatomine presence. Here, the collaboration between oil palm cultivators and public health organizations is essential. Secondly, triatomine populations found in plantations should be toxicologically tested using biological or biochemical assays as those used in our study. The monitoring of triatomines should include population genetics studies identifying the presence and frequency of mutations related to insecticide resistance. Toxicological studies should include other pyrethroids also reported for triatomine control (e.g. cypermethrin and $\alpha$-cyhalothrin) to determine if insecticide cross-resistance occurs as well. Thirdly, control strategies should be developed to impact successfully on both oil palm pests and palm-infesting triatomines. Insecticides and dosages used for oil palm pest control must also ensure triatomine control. Studies about the effect of current chemical pest control over triatomines should be performed. Then, insecticides, formulations or spraying frequencies should be modified to warrant the control of both pests and triatomines. Insecticide rotation can be considered also as a resistance management strategy. However, the rotation between insecticides such as organophosphates/carbamates and pyrethroids is not suggested based on toxic potency, toxicological risk, and quality of the formulations [3].

\section{Conclusions}

Rhodnius prolixus collected from oil palms showed resistance to pure and commercial deltamethrin. This resistance may be caused by continuous exposition to the insecticide, which is suggested for the control of oil palm pests. Possible resistance mechanism in $R$. prolixus from oil palms are the increased activity of detoxifying enzymes, such as esterases and oxidases, which reduce the insecticide damage. Deltamethrin resistance was also observed in $R$. prolixus from native palms, but with a lower grade of resistance. Insecticide resistance in triatomines from oil palms may become a concern for public health if resistant triatomines migrate toward urban settings and hinder traditional chemical vector control. Pest management in oil palm plantations is extremely important for crop production; however, a pest control strategy that includes triatomine surveillance and toxicological monitoring should be considered. In the field of public health, these results are very important to redirect control strategies in triatomines, it is recommended to expand the studies to other areas to have more information.

\section{Abbreviations}

WHO: World Health Organization; LD50: lethal dosage 50; LD90: lethal dosage 90; RH: relative humidity; GST: glutathione S-transferases; MFO: mixed-function oxidases.

\section{Acknowledgements}

We thank Juan Manuel Cordovez (BIOMAC, Universidad de Los Andes, Colombia) and Jorge Molina and Laura Tamayo (CIMPAT, Universidad de Los Andes, Colombia) for their helpful discussion and suggestions. We also thank Alejandra Herran (Universidad Distrital, Colombia) and Cielo León (CIMPAT, Universidad de Los Andes, Colombia) for their collaboration in the biochemical assays. We thank to the Biological Sciences department of the Universidad de Los Andes and the Entomology Lab in the Instituto Nacional de Salud for allowing us the use of their facilities and their technical support.

\section{Authors' contributions}

JMC and CG conceived the idea, JMC conducted the biological assays, JMC, PF and LS carried out the biological analysis. All authors read and approved the final manuscript.

\section{Funding}

This study was supported by the Colciencias Call 647 and Science Faculty of the Universidad de Los Andes, Project code: INV-2018-48-1387.

\section{Availability of data and materials}

Data supporting the conclusions of this article are included within the article. The datasets generated and analyzed during the present study are available from the corresponding author upon reasonable request.

\section{Ethics approval and consent to participate}

Not applicable.

\section{Consent for publication \\ Not applicable.}

\section{Competing interests}

The authors declare that they have no competing interests.

\section{Author details}

${ }^{1}$ Centro de Investigaciones en Microbiología y Parasitología Tropical (CIMPAT), Departamento de Ciencias Biológicas, Universidad de Los Andes, Bogotá D.C., Colombia. ${ }^{2}$ Laboratorio de Entomología, Instituto Nacional de Salud, Bogotá D.C., Colombia.

Received: 9 December 2019 Accepted: 28 March 2020

Published online: 03 April 2020

\section{References}

1. Moncayo Á, Silveira AC. Current epidemiological trends for Chagas disease in Latin America and future challenges in epidemiology, surveillance and health policy. Mem Inst Oswaldo Cruz. 2009;104:17-30.

2. WHO/Department of Communicable Disease Prevention C and E. Past and present of Chagas vector control and future needs. Position paper. Rome: World Health Organisation; 1999.

3. Mougabure-Cueto G, Picollo MI. Insecticide resistance in vector Chagas disease: evolution, mechanisms and management. Acta Trop. 2015;149:70-85.

4. Dias JCP, Silveira AC, Schofield CJ. The impact of Chagas disease control in Latin America: a review. Mem Inst Oswaldo Cruz. 2002;97:603-12.

5. Catalá SS, Noireau F, Dujardin JP. Biology of triatominae. In: Telleria J, Tibayrenc M, editors. American trypanosomiasis Chagas disease. One hundred years of research. 2nd ed. Amsterdam: Elsevier; 2017. p. 145-68.

6. DÁvila Pessoa GC, Albajar Vinãs P, Luiz Rosa AC, Diotaiuti L. History of insecticide resistance of Triatominae vectors. Rev Soc Bras Med Trop. 2015;48:380-9.

7. Fox I, Bayona IG, Orozco HI. Toxicity of DDT, dieldrin, malathion and fenthion to Rhodnius prolixus in the laboratory. Bull World Health Organ. 1966;35:974-6. 
8. Pedrini N, Mijailovsky SJ, Girotti JR, Stariolo R, Cardozo RM, Gentile A, et al. Control of pyrethroid-resistant chagas disease vectors with entomopathogenic fungi. PLoS Negl Trop Dis. 2009;3:e434.

9. Ministerio de Agricultura. Base Agrícola EVA 2007-2016 (P). 2016. http:// www.agronet.gov.co/estadistica/Paginas/home.aspx. Accessed 14 June 2019.

10. Guhl F, Pinto N, Marín D, Herrera C, Aguilera G, Naranjo JM, et al. Primer reporte de Rhodnius prolixus Stal, en Elaeis guineensis variedad Papúa, en plantaciones agroindustriales de Villanueva, Casanare. Biomedica. 2005:25:158-9.

11. Erazo D, Gottdenker NL, González C, Guhl F, Cuellar M, Kieran TJ, et al. Generalist host species drive Trypanosoma cruzi vector infection in oil palm plantations in the Orinoco region, Colombia. Parasit Vectors. 2019;12:274.

12. Guhl F, Aguilera G, Pinto N, Vergara D. Actualización de la distribución geográfica y ecoepidemiología de la fauna de triatominos (Reduviidae: Triatominae) en Colombia. Biomédica. 2007;27:143-62.

13. Parra GJ, Flórez M, Angulo VM, editors. Vigilancia de Triatominae (Hemiptera: Reduviidae) en Colombia. Sic Editorial Ltda: Bogotá D.C; 2015.

14. Abad-Franch F, Lima MM, Sarquis O, Gurgel-Gonçalves R, Sánchez-Martín M, Calzada J, et al. On palms, bugs, and Chagas disease in the Americas. Acta Trop. 2015;151:126-41

15. Ceccarelli S, Balsalobre A, Medone P, Cano ME, Gonçalves RG, Feliciangeli $D$, et al. Data descriptor: DataTri, a database of American triatomine species occurrence. Sci Data. 2018:5:180071.

16. Fedepalma. Guía de prácticas agrícolas en el cultivo de palma de aceite ya establecido. Bogotá D.C.: Fedepalma; 2012.

17. Fedepalma. Guía de bolsillo para el reconocimiento y manejo de las principales enfermedades e insectos plaga en el cultivo de la palma de aceite. Bogotá D.C.: Fedepalma; 2016.

18. Cenipalma. Biología, hábitos y manejo de Rhynchophorus palmarum L. (Coleoptera: Curculionidae). Boletín técnico. Bogotá D.C.; 2010.

19. Ministerio de la protección social, Instituto Nacional de Salud, Organización Panamericana de la Salud. Gestión para la vigilancia entomológica y control de la transmisión de la enfermedad de Chagas. 2013.

20. Martínez LC, Plata-Rueda A, Zanuncio JC, Serrao JE. Comparative toxicity of six insecticides on the Rhinoceros beetle (Coleoptera: Scarabaeidae). Florida Entomol. 2014;97:1056-62.

21. Aldana de la Torre RC, Aldana de la Torre JA, Calvache Guerrero H, Franco Bautista PN. Manual de plagas de la palma de aceite en Colombia. 4th ed. Bogotá, D.C.: Cenipalma; 2010.

22. Sáenz Aponte A, Ospino J. Efectividad de insecticidas para el control del barrenador de raíces de palma Sagalassa valida Walker. Palmas. 2007;28:31-8

23. Rodríguez González G, Silva Acuña R, Cásares Moizant R, Barrios Maestre R, Díaz Quintana A, Fariñas Marcano J. Tecnología agronómica de la palma aceitera (Elaeis guineensis Jacq,) y manejo integrado de su defoliador Opsiphanes cassina Felder (Lepidoptera: Brassolidae) en plantaciones comerciales del estado Monagas, Venezuela. Rev Científica UDO Agrícola. 2012:12:584-98

24. Martínez LC, Plata-Rueda A, Rodríguez-Dimaté FA, Mendonça Campos J, dos Santos Júnior VC, Da Silva Rolim G, et al. Exposure to insecticides reduces populations of Rhynchophorus palmarum in oil palm plantations with bud rot disease. Insects. 2019:10:111.

25. Angulo VM, Esteban L, Luna KP. Attalea butyracea próximas a las viviendas como posible fuente de infestación domiciliaria por Rhodnius prolixus (Hemiptera: Reduviidae) en los Llanos Orientales de Colombia. Biomédica. 2012;32:277-85.

26. Urbano P, Poveda C, Molina J. Effect of the physiognomy of Attalea butyracea (Arecoideae) on population density and age distribution of Rhodnius prolixus (Triatominae). Parasit Vectors. 2015;8:199.

27. Angulo VM, Esteban L. Nueva trampa para la captura de triatominos en hábitats silvestres y peridomésticos. Biomédica. 2011:31:264-8.

28. Lent H, Wygodzinsky P. Revision of the Triatominae (Hemiptera, Reduviidae), and their significance as vectors of Chagas' disease. Bull Am Museum Nat Hist. 1979;163:123-520.

29. Fitzpatrick S, Feliciangeli MD, Sanchez-Martin MJ, Monteiro FA, Miles MA. Molecular genetics reveal that silvatic Rhodnius prolixus do colonise rural houses. PLoS Negl Trop Dis. 2008;2:e210.
30. WHO Taller sobre la evaluación de efecto insecticida sobre triatominos. Protocolo de evaluación de efecto insecticida sobre triatominos. Acta Toxicol Argentina. 1994;2:29-32.

31. Valle D, Montella IR, Ribeiro RA, Viana Medeiros PF, Martins Junior A de J, Pereira Lima JB. Quantification methodology for enzyme activity related to insecticide resistance in Aedes aegypti. Brasilia, Brasil: Ministério da Saúde: 2006.

32. Davila-Barboza J, Villanueva-Segura OK, Lopez-Monroy B, Ponce-Garcia G, Bobadilla-Utrera C, Montes-Rincon M, et al. Novel Kdr mutations (K964R and A943V) in pyrethroid resistant populations of Triatoma mazzottii Usinger and Triatoma longipennis Usinger from Mexico and detoxifying enzymes. Insect Sci. 2018;26:809-20.

33. Wheeler MW, Park RM, Bailer AJ. Comparing median lethal concentration values using confidence interval overlap or ratio tests. Environ Toxicol Chem. 2006;25:1441-4.

34. Ritz C, Baty F, Streibig JC, Gerhard D. Dose-response analysis using R. PLoS One. 2015;10(12):e0146021.

35. WHO. Environmental health criteria 97-deltamethrin. Geneva: World Health Organization; 1990.

36. Vassena CV, Picollo MI, Zerba EN. Insecticide resistance in Brazilian Triatoma infestans and Venezuelan Rhodnius prolixus. Med Vet Entomol. 2000;14:51-5.

37. Corley RHV, Tinker PB. The oil palm. 5th ed. Hoboken:Wiley Blackwell; 2016.

38. Plata-Rueda A, Martínez LC, Fernandes FL, De Sousa Ramalho F, Zanuncio $J C$, Serrão JE. Interactions between the bud rot disease of oil palm and Rhynchophorus palmarum (Coleoptera: Curculionidae). J Econ Entomol. 2016;109:962-5.

39. González Audino P, Vassena C, Barrios S, Zerba E, Picollo MI. Role of enhanced detoxication in a deltamethrin-resistant population of Triatoma infestans (Hemiptera, Reduviidae) from Argentina. Mem Inst Oswaldo Cruz. 2004;99:335-9.

40. Picollo MI, Vassena C, Santo Orihuela P, Barrios S, Zaidemberg M, Zerba E. High resistance to pyrethroid insecticides associated with ineffective field treatments in Triatoma infestans (Hemiptera: Reduviidae) from northern Argentina. J Med Entomol. 2005:42:637-42.

41. Santo Orihuela PL, Vassena CV, Zerba EN, Picollo MI. Relative contribution of monooxygenase and esterase to pyrethroid resistance in Triatoma infestans (Hemiptera: Reduviidae) from Argentina and Bolivia. J Med Entomol. 2008;45:298-306.

42. Germano MD, Santo-Orihuela P, Roca-Acevedo G, Toloza AC, Vassena C, Picollo Ml, et al. Scientific evidence of three different insecticide-resistant profiles in Triatoma infestans (Hemiptera: Reduviidae) populations from Argentina and Bolivia. J Med Entomol. 2013;49:1355-60.

43. Hemingway J, Ranson H. Insecticide resistance in insect vectors of human disease. Annu Rev Entomol. 2000;45:371-91.

44. Yang E, Yang Y, Wu S, Wu Y. Relative contribution of detoxifying enzymes to pyrethroid resistance in a resistant strain of Helicoverpa armigera. J Appl Entomol. 2005;129:521-5.

45. Prapanthadara LA, Koottathep S, Promtet N, Hemingway J, Ketterman AJ. Purification and characterization of a major glutathione S-transferase from the mosquito Anopheles dirus (species B). Insect Biochem Mol Biol. 1996:26:277-85.

46. Castro LA, Peterson JK, Saldaña A, Perea MY, Calzada JE, Pineda V, et al. Flight behavior and performance of Rhodnius pallescens (Hemiptera: Reduviidae) on a tethered flight mill. J Med Entomol. 2014;51:1010-8.

47. Jácome-Pinilla D, Hincapie-Peñaloza E, Ortiz MI, Ramírez JD, Guhl F, Molina J. Risks associated with dispersive nocturnal flights of sylvatic Triatominae to artificial lights in a model house in the northeastern plains of Colombia. Parasit Vectors. 2015;8:600.

48. Feliciangeli MD, Sanchez-Martin M, Marrero R, Davies C, Dujardin JP. Morphometric evidence for a possible role of Rhodnius prolixus from palm trees in house re-infestation in the State of Barinas (Venezuela). Acta Trop. 2007;101:169-77.

49. D'Alessandro A, Barreto P, Saravia N, Barreto M. Epidemiology of Trypanosoma cruzi in the oriental plains of Colombia. Am J Trop Med Hyg. 1984;33:1084-95

50. Dias-Lima AG, Sherlock ÍA. Sylvatic vectors invading houses and the risk of emergence of cases of Chagas disease in Salvador, State of Bahia, northeast Brazil. Mem Inst Oswaldo Cruz. 2000;95:611-3. 
51. Noireau F, Carbajal-De-La-Fuente AL, Lopes CM, Diotaiuti L. Some considerations about the ecology of Triatominae. An Acad Bras Cienc. 2005;77:431-6.

52. Castro MCM, Barrett TV, Santos WS, Abad-Franch F, Rafael JA. Attraction of Chagas disease vectors (Triatominae) to artificial light sources in the canopy of primary Amazon rainforest. Mem Inst Oswaldo Cruz. 2010;105:1061-4.
53. Castiblanco C, Etter A, Aide TM. Oil palm plantations in Colombia: a model of future expansion. Environ Sci Policy. 2013;27:172-83.

\section{Publisher's Note}

Springer Nature remains neutral with regard to jurisdictional claims in published maps and institutional affiliations.
Ready to submit your research? Choose BMC and benefit from:

- fast, convenient online submission

- thorough peer review by experienced researchers in your field

- rapid publication on acceptance

- support for research data, including large and complex data types

- gold Open Access which fosters wider collaboration and increased citations

- maximum visibility for your research: over $100 \mathrm{M}$ website views per year

At BMC, research is always in progress.

Learn more biomedcentral.com/submissions 